\title{
Lumen
}

Selected Proceedings from the Canadian Society for Eighteenth-Century Studies

\section{The Sexual Politics of the Eye: Women in Pope's Poetry}

\section{Susan Drodge}

Volume 13, 1994

URI : https://id.erudit.org/iderudit/1012523ar

DOI : https://doi.org/10.7202/1012523ar

Aller au sommaire du numéro

Éditeur(s)

Canadian Society for Eighteenth-Century Studies / Société canadienne d'étude du dix-huitième siècle

ISSN

1209-3696 (imprimé)

1927-8284 (numérique)

Découvrir la revue

Citer cet article

Drodge, S. (1994). The Sexual Politics of the Eye: Women in Pope's Poetry.

Lumen, 13, 79-85. https://doi.org/10.7202/1012523ar d'utilisation que vous pouvez consulter en ligne.

https://apropos.erudit.org/fr/usagers/politique-dutilisation/ 


\section{The Sexual Politics of the Eye: Women in Pope's Poetry}

In an age of prescribed female self-abnegation, the active, surveying eyes of Alexander Pope's women reflect feminine sensuality and passion or, as in the case of the conceited Belinda, sexual independence and a lack of passion. While the verbal communication of the eighteenth-century bourgeois female was supposedly limited by feminine conduct books, the extensive non-verbal communication of Pope's female subjects suggests a rather subversive approach to such rigid morality. Ellen Pollak writes that 'feminine conduct books... were distinguished by an advocacy of purely passive female virtues' (2). Yet Pope's imaging of the female gaze clearly reflects the erotic impulses of the single woman. In Epistle to Miss Blount on her Leaving Town after the Coronation, he equates the initial detection of female gaze with awakening sexuality, writing,

As some fond virgin, whom her mother's care

Drags from the town to wholesome country air,

Just when she learns to roll a melting eye,

And hear a spark, yet think no danger nigh. (11. 1-4)

Pope suggests that the erotic gaze of the single woman is a disagreeable, yet learned mannerism. As a conditioned response, we might well ask: who is the teacher of female gaze? Pope offers no satisfactory answer. In the first canto of The Rape of the Lock, he writes, alluding to social factors which influence nymphs' behaviour, "Tis these that early taint the female soul,/Instruct the eyes of young Coquettes to roll' (1l. 87-88).

Some of Pope's most dignified women are products of such female conditioning, erotic beings who manipulate their ocular expressions to their sexual interest. In Elegy to the Memory of an Unfortunate Lady, Pope regretfully discloses that her 'love-darting eyes must roll no more' (1.34). Her 'unfortunate' end seems to have been precipitated by her capacity to 'love too well' (1. 6). The lady's self-imposed banishment and alienation from British society suggests that her passion transgressed eighteenth-century codes and morality. Pope's accolade for the gazeless 
Martha Blount in Epistle to a Lady: of the Characters of Women is in obvious contrast to his exalted lament for the unfortunate lady. The virtues of Martha Blount which Pope praises in this Epistle correspond to those passive female ideals promoted by conduct books: she 'Charms by accepting, by submitting sways,/Yet has her humour most, when she obeys' (ll. 263-64). This paragon of virtue is, despite the poet's commendation, without true character and essentially sexless. Little delight is evidenced in the poet's rather dispassionate and aloof accolade. Judging by his poetic tone, he is far more captivated and charmed by the sexual women he depicts, such as Eloisa and the alluring coquettes of Epistle to a Lady. There is certainly admiration and respect in Pope's poetic treatment of the passionate, yet unfortunate lady of his earlier Elegy. His ambiguous stance on female sexuality is reflected in his respectful handling of both the passion of the unfortunate lady and the antithetical lack of intensity of Martha Blount.

Pope's recurrent attention to the consequence of gaze in his depiction of the female situation suggests that such non-verbal communication was a source of social and sexual expression, perhaps even empowerment, for the eighteenth-century woman. In their study of the gaze and its social history, Michael Argyle and Mark Cook observe,

Some literary and anthropological references confirm that gaze is very important in courtship. Casanova described how women in eighteenth-century Madrid relied on glances as an invitation, because the repressive moral atmosphere of the day prevented any other approach. Stendhal anticipated current ideas by a hundred years when he noted that women gave him invitations by gaze, because they could later 'repudiate' the contract as it could not be quoted. Francis Bacon described the appropriate gaze pattern to use: 'sudden glances and darting of the eye' but not a fixed stare. (63)

In the first of his Pastorals, Pope seemingly sanctions the female gaze as a means of invitation. In Spring: the First Pastoral, he advocates a decorous application of female gaze in the ritual of courtship: he writes,

The sprightly Sylvia trips along the green,

She runs, but hopes she does not run unseen;

While a kind glance at her pursuer flies,

How much at variance are her feet and eyes! (11. 57-60)

Sylvia's gaze is 'kind,' playful and inviting, indicating her acquiescence to her male pursuer. Yet, we might justly ask: who is she really looking at? She glances behind to make sure that she remains the object of 
pursuit. As John Berger incisively notes, 'The surveyor of woman in herself is male' (47). In seeking her pursuer's gaze, she is making herself the object of male passion. Despite her seemingly seductive lead with her inviting gaze, she is objectifying herself as the willing prey of this ritual of courtship.

As Valerie Rumbold speculates, Pope's lengthy friendship with the Blount sisters, as well as his own social marginality - a consequence of his Roman Catholicism and ill health - likely engendered a certain empathy for his socially defenseless female subjects. Pope characterizes Belinda as a helpless rebel against the dictates of courtship and his era's insistence on women marrying for social station. His satire of the eighteenth-century bourgeoisie in The Rape places Belinda within the context of a superficial, male-dominated society, a society in which the female is primarily sustenance for the male ego. The eye imagery associated with Belinda reflects her rebel nature; rather than responding to the gaze of the male admirer in a decorous, inviting manner as does Sylvia, we see Belinda, 'Bright as the sun, her eyes the gazers strike,/And, like the sun, they shine on all alike' (ll. 13-14). As Argyle and Cook write of the traditional courtship gaze, 'Courtship approaches involve special kinds of gaze... with bright but slightly narrowed eyes, gazing at the other' (62). Belinda's eyes may be bright, but she cares not who is admiring her, only that she is being admired. However misguided, her conceit is initially a means of social empowerment which permits her to operate rather independently within the strictures of her society's rituals. As Geoffrey Carnall writes,

Belinda is a priestess of the religion of vanity. It is appropriate that she should have the scriptures of the true religion as some mere miscellaneous adjunct among the puffs and powders, patches and billets-doux. However she is doing it, she is clearly denying the traditional authority of the Bible in a quite radical way. (131)

Belinda further denies eighteenth-century doctrine which ordained that the woman's role in social intercourse was to complement the male ego. Belinda's vanity temporarily negates her subservience to the male ego, for she caters only to her own.

Belinda's sexual independence is tamed during the course of The Rape by her male counterpart, the superficial, conceited Baron. The narcissism displayed in her refusal to participate in a mutual gaze with a Lord is ultimately punished and, as a result, it seems, even her eyes are tamed. The opening lines of The Rape suggest her broken spirit and the moral transformation of her gaze: Pope writes that 'This ev'n Belinda may vouchsafe to view' (l. 3). She has been socially shamed, and the eye 
imagery associated with Belinda in the opening of the first canto suggests a learned or negatively conditioned decorum. During the course of The Rape, Belinda's eyes illuminate her evolution of self. Felicity Nussbaum writes that, in both The Rape and Epistle to a Lady, 'women divide themselves into prudes and coquettes' (139). The broken Belinda who may now vouchsafe to view The Rape has been transformed from a coquette into a prude, and her new decorum of gaze reflects the metamorphosis.

Pope's satirical eye imagery in the concluding canto of The Rape suggests that the murderous gaze was the primary means for a single woman to avenge herself and challenge the male in eighteenth-century high society. While the Baron's violence takes the form of a physical violation of Belinda's person, her fury effects only metaphorical, ocular violence. The lightning builds in her eyes as the poem progresses and she must empower herself against her male oppressors. Pope writes, 'See fierce Belinda on the Baron flies,/With more than usual lightning in her eyes' (canto V, 11. 75-6; emphasis mine). In the concluding canto of the satire, the eyes become murder weapons, the means of female revenge upon the male:

While thro' the press enrag'd Thalestris flies,

And scatters deaths around from both her eyes,

A Beau and Witling perish'd in the throng,

One dy'd in metaphor, and one in song.

'O cruel nymph! a living death I bear,'

Cry'd Dapperwit, and sunk beside his chair.

A mournful glance Sir Fopling upwards cast,

'Those eyes are made so killing' - was his last. (canto V, 11. 57-64)

Despite Clarissa's didactic pronouncement that, 'Beauties in vain their pretty eyes may roll,' Belinda's 'pretty eyes' become the vehicle for her revenge and reclamation of self (canto $\mathrm{V}, 11.33-5)$. In the concluding verse of The Rape, Pope pays a certain homage, however satirical, to both Belinda's hair and her eyes - two of her foremost expressions of self:

Not all tresses that fair head can boast,

Shall draw such envy as the Lock you lost.

For, after all the murders of your eye,

When, after millions slain, yourself shall die;

When those fair suns shall set, as set they must,

And all those tresses shall be laid in dust; 
This Lock, the Muse shall consecrate to fame,

And 'midst the stars inscribe Belinda's name. (ll. 143-50)

Without the purgation of shame and vengeance available through the medium of the murderous gaze, we might well assume that Belinda would not have reconciled her 'rape' and achieved her apparently new understanding of decorous behaviour suggested in the opening canto of the poem.

Underlying the playful satire of the female gaze in The Rape, Pope presents a stifling society where women cannot openly communicate their selfhood, independence, nor their frustrations over being victims of male abuse. Just as it is indecorous for the dauntless Belinda to win at ombre, it is a signal of her irreverence and supposedly antisocial attitude to 'shine on all alike' without participating in a mutual gaze with the aggressive Baron. In not responding to the gaze of her admirer, Belinda not only suggests a certain narcissism, but a certain sexual independence, perhaps even disinterest. W.W. Robson suggests the necessity of proper contextualization in criticizing Pope's treatment of such female characters as Belinda, writing that

his view of women has always been the subject of controversy from his own time to ours, and hostile things have been said about it... But it may be that this does not take sufficient allowance of the realities of the society and culture in which Pope was writing his compliments, and his sermons, to women. As Pat Rogers puts it (1974), he is telling them 'how to succeed in a man's world' (p. 91), a world in which they were admired, respected, teased, patronized and cajoled by men, but not treated with intellectual respect. Pope can be seen not as reinforcing the constrictions of the polite code but showing, from the inside, how to defeat them. (200)

The patriarchal society of The Rape allows little respect for Belinda's body or her spirit, despite her social desirability as a 'leisured companion' (Rumbold 1). Yet, in depicting the futility of a woman's rebellion within a society where the status of the genders is a rigid hierarchy, Pope ultimately advocates a certain submission to feminine conduct ideals. While he depicts the injustice and sexism of eighteenth-century bourgeois society, he offers no real alternative for the female who must live within moral and social prescription.

In his Epistle to a Lady, Pope again applies eye imagery to further his satirical purposes. Of the beautiful, but morally unacceptable female, he concludes, 'Her Tongue [is] bewitch'd as odly as her Eyes' (1. 47). He suggests that the ocular expressions of coquettes are as blatantly vulgar 
as their speech. In contrast, he censures the dispassionate Cloe for her lack of participation in mutual gaze:

She, while her Lover pants upon her breast,

Can mark the figures on an Indian chest;

And when she sees her Friend in deep despair,

Observes how much a Chintz exceeds Mohair. (1l. 167-70)

Paradoxically, Pope censures his female subjects for indecorous gaze, as well as for refusal to participate in mutual gaze.

Pope's most sensitive treatment of the gaze is to be found in Eloisa to Abelard, a poem in which the voice and passion of the female is privileged over the silence and control of the male. Yet, it is the male gaze that dominates the eye imagery of this poem; the female gaze is more response than invitation. For both her profound passion and her moral rectitude, Eloisa is Pope's most paradoxical, yet riveting female characterization. With her sexual history backgrounding the poem, she is also the most blatantly erotic of Pope's women. Through the image of the gaze, however, Pope suggests Eloisa was innocent in the initiation of a sexual relationship with Abelard; she was not a coquette with rolling eyes, but rather, as she reflects, 'Guiltless I gaz'd' (1. 65). It is notably the eyes of Abelard, rather than those of Eloisa, which yield 'delicious poison' and are 'deluding' (1. 122; 1. 282). Of her lover, Eloisa writes, 'Fair eyes, and tempting looks (which yet I view!)/Long lov'd, ador'd ideas all adieu!' (ll. 295-96). Here the idea of establishing a mutual gaze is sadly ironized. While spending the remainder of her days in pious servitude, her only means of sexual recollection or re-experience is her sight. She writes to Abelard:

Come! with thy looks, thy works, relieve my woe;

Those still at least are left thee to bestow.

Still on that breast enamour'd let me lie,

Still drink delicious poison from thy eye. (11. 119-22)

The gaze of Eloisa, much like that of Sylvia, is represented primarily as a response to that of the male aggressor. Rebecca Ferguson writes that 'At certain moments of crisis, Eloisa invokes her own name in the third person, which in itself represents a form of self-assertion' (19). Yet such invocations, as well as Eloisa's willingness to establish mutual gaze with Abelard, might appropriately be seen as an objectification of the self or the surrendering of her self to her male lover. While such surrender is indeed a romantic ideal, we might well ask what Pope is advocating as his own female ideal. While characterizing certain female subjects as 
rather independent thinkers and sympathetic victims of patriarchal expectations, he never goes so far as to offer any viable alternative to female submission. Ultimately, the woman and her gaze are left powerless within the social cosmos of Alexander Pope's poetry.

\section{SUSAN DRODGE}

Memorial University of Newfoundland

\section{Works Cited}

Argyle, Michael and Mark Cook. Gaze and Mutual Gaze. New York: Cambridge: Cambridge University Press, 1976.

Berger, John. Ways of Seeing. New York: Penguin, 1977.

Carnall, Geoffrey. 'Belinda's Bibles.' In Alexander Pope: Essays for the Tercentenary. Ed. Colin Nicholson. Aberdeen: Aberdeen University Press, 1988. 130-38.

Nussbaum, Felicity A. "The Glory, Jest, and Riddle of the Town”: Women in Pope's Poetry.' The Brink of All We Hate: English Satires on Women 1660-1750. Lexington: University Press of Kentucky, 1984. 137-58.

Pollak, Ellen. The Poetics of Sexual Myth: Gender and Ideology in the Verses of Swift and Pope. Women in Culture and Society Series. Chicago: University of Chicago Press, 1985.

Pope, Alexander. Poetical Works. Ed. Herbert Davis with intro. by Pat Rogers. New York: Oxford University Press, 1989.

Robson, W.W. 'Text and Context: Pope's "Coronation Epistle".' In Alexander Pope: Essays for the Tercentenary. Ed. Colin Nicholson. Aberdeen: Aberdeen University Press, 1988. 195-205.

Rumbold, Valerie. Women's Place in Pope's World. Cambridge Studies in Eighteenth-Century English Literature and Thought 2. New York: Cambridge University Press, 1989. 